\title{
University Social Responsibility Initiatives: An Empirical Study of Private and State Universities of Rajasthan
}

\author{
Devika Sharma $^{1^{\star}}$, Dr. Rashmi Sharma ${ }^{2}$ \\ ${ }^{1}$ School of Management, Research Scholar, JECRC University, Jaipur (Raj.), India \\ ${ }^{2}$ School of Management, Faculty of Management, JECRC University, Jaipur (Raj.), India
}

Abstract

Social responsibility is a leading term in today's world, whether it is related to profit-making corporations or non-profit organizations. Many corporations do social responsibility in terms of corporate social responsibility, but it is in terms of university social responsibility if we talk about universities. Universities have taken up different types of social responsibility initiatives in both developing and developed countries. Through social responsibility initiatives, there is a need to understand private and state universities' involvement in society and the environment. By imparting knowledge and empowering students, universities serve the Society; this study would observe other universities' social responsibility initiatives towards their Society and Environment. The purpose of this paper is to explore the impact of social responsibility initiatives taken up by private and state universities of Rajasthan towards Society and environment. This paper is using survey research method based on simple random sampling and studying twenty private and state universities of Rajasthan by focusing two main dimensions service to Society and service to environment. The findings of this research show that Private and State Universities are doing more social responsibility initiatives towards Society rather than environment and based on hypothesis testing, it is concluded that there is no statistically significant difference between social responsibility initiatives taken up by private and state universities of Rajasthan while on the basis of the correlation and regression results, there is a significant impact of social responsibility initiatives taken up by private and state universities of Rajasthan towards society and environment. Social Responsibility Initiatives in state universities have a more positive attitude towards Society.

Keywords:

university social responsibility, university social responsibility initiatives, individual social responsibility, social responsibility, corporate social responsibility

Article Received: 10 August 2020, Revised: 25 October 2020, Accepted: 18 November 2020

\section{Introduction}

India is the strongest democracy globally, and the secondmost populous country in the world and faces many challenges related to the environment and society. Social responsibility is an emerging concept in the current time, whether it is related to a profit-making organization or a non-profit organization. In terms of corporate social responsibility, most corporations are socially responsible, but if we talk about Universities, it is doing in terms of University social Responsibility. University Social Responsibility provides a unique platform through which we can nurture the students and make them socially responsible for community development. USR, CSR, and ISR play a significant role in forming the modern world by supplying socially conscious educational institutions, people, and businesses (TARA Panjwani 2019, April 08).

In the private sector, much of the CSR operations are carried out by young people between the ages of 18 and
25 years, where, as in academia, we can very effectively tap this age demographic and, with good channeling, we can redirect young people to the benefit of society. Many universities are doing SR initiatives either in the form of tree plantation, Blood donation camps, etc. or in the way of well-being, health \& safety of employees. Even the International Organizations for Standardization has also taken it seriously and has launched ISO:26000 for providing guidelines on social responsibility.

CSR activities by private school organizations in the Philippines are now seen as an expenditure initiative to ensure financial benefits brought about by the effectiveness and loyalty of the partners and improved public reputation, even though earlier it was seen as an expense to the organization. (Valdez 2012) and emerging relationships between CSR and universities can empower society through clearly defined histories and traditions (Mehta and Humanity 2011). Suppose institutions want to 
be effective in the CSR approach. In that case, CSR acts need to be internalized and endorsed by management that offers a positive image and a clear competitive edge, and higher education institutions need to implement Corporate Social Responsibility at both the institutional and academic levels through curricular practices. (Dahan and Senol 2012) and the importance of the social responsibility of companies in India in education and technology through CSR initiatives as the long-term vision of Indian companies to create higher-learning global institutions in India with the Government of the state, including DA-IICT in Gujarat, the Shakti HUL Project, and Aurangabad TATA Institute of Hotel Management (Nandi 2013). CSR Initiatives in Higher Education Institutions provide practical knowledge of fundraising, teamwork, project management under challenging circumstances based on CSR projects (Lahaye, Cristache et al. 2012). Even the role of CSR in education is to reconcile the skills gap with considerable innovation with the aid of businesses by providing funding for research and development, organizing various workshops, training and growth programs, crossexchange programs, infrastructural support, and providing quality education facilities, since they are also consumers/users of qualified education (Chopra and Marriya 2014) while some of the responsibilities that universities have are primarily oriented, towards maintaining their own integrity which can be termed USR and found that there is a requirement for the establishment of special education programs at universities to promote CSR and meet USR (Karima, Oshima et al. 2006).

\section{A. Social Responsibility extension to the education sector:}

Several reasons explain the extension of the concept of social responsibility to universities: -

- As per The Hindu newspaper dated $17^{\text {th }}$ April, 2013 India is the country with the youngest population that has a lot of potentials if the youth is channelized for constructive purposes and made to act on social issues (Shivkumar 2013, April 17)

- Universities create the potential staff of public and private corporation.

- Universities are contributing to provincial professional learning and employability.

- Universities are expected to play a significant role in solving environmental issues by incorporating the idea of sustainability into their curriculum.

B. Definition of University Social Responsibility:
University Social Responsibility is one of the strategic dimensions of a university targeting the well-being and involvement of all stakeholders in encouragement and management of holistic view of economic, social, environmental, and academic knowledgeability as well as acting as a hub between corporates and local and global environmental needs of the society by creating shared value activities and projects to achieve high sustainability (Kouatli 2019).

\section{Stakeholders, Areas and components of the University Social Responsibility:}

Students, Graduates, Parents, Schools, Faculty, Administrative staff, Communities close to the University, Suppliers, Public institutions, Business Civil Society Organizations, Associations Accrediting institutions, media, other academic institutions, and educational authorities can be considered as the stakeholders of the university. At the same time, USR areas can be described in 5 components, which are Teaching, Research, Extension of Social Projection, Operational Administration, and Leadership and Strategy (Gomez, Naveira et al. 2018).

\section{Dimensions of the University Social Responsibility:}

University Social Responsibility dimensions can be divided into four dimensions: environmental, social, finance, and an economic dimension (Capocchi, Orlandini et al. 2019).

The best universities are socially conscious, and their social projects in the public sphere are conveyed. Their pictures are not merely synonymous with social responsibility in higher education institutions. Still, the future development of each country and the world as a whole should be on high-priority (Peicheva 2019). Some social responsibility programmes in universities fund homeless animals that improve connexions between humans and animals and promote a healthy living environment for all living creatures. Social responsibility component has a significant impact on students with the effect depends on the degree in which they are studied (Goncu and Gorgulu 2018).

Some of the Universities in India are doing Social Responsibility initiatives by establishing the Center of Excellence on Ecological Farming for revolutionary best farming practices, offering a free certificate course in Agroecology, organizing a Management Development Program on Solid-Liquid and Waste Management, offering digital farming solutions by an initiative of Escorts called the Digital mobile app and conducting The 
College Bazaar for promoting women entrepreneurs etc. The University Social Responsibility initiative is an essential link between students and communities, which provides an excellent opportunity to learn, contribute to social justice, and do the right thing. European universities are dedicated to educating students on society's challenges as actively active citizens, not as human identities but as social persons responsible for climate change, global inequality, environmental conservation, recycling, and other facets (Vasilescu, Barna et al. 2010).

Partnership between businesses and the university has a vital role to play in learning from each other best practices, as universities can learn how to manipulate minds and produce socially conscious workers who work to be good citizens while universities can learn business approaches to develop, coherently, and incorporate personalized social programs (TARA Panjwani 2019, April 08). Universities have taken up different types of social responsibility initiatives in both developing and developed countries. Public and private US universities, particularly those linked to sustainability, are not deeply committed to the online divulgation of SR information (Garde Sanchez, Rodriguez Bolivar et al. 2013). The University should also seek to recognize prospects for change and future obstacles for the USR. University leads to 'social capital creation' by interacting with the community and supporting all community layers in terms of capacity building, community empowerment, the development of a healthy lifestyle, and good citizenship (Shaari.R.et.al. 2018).

The responsible initiatives for employees and students by higher education institutions and B-Schools can be done by practicing the social responsibility initiatives towards employee would help in stress management, retention, work-life balance, performance and reward management and connect students towards social issues by organizing workshops, endorsing ecological projects, campus pictorial icons, social and environmental talks and debates (Mishra and Research 2013), and the perception of students on Corporate Social Responsibility activities can be measured on the basis of CSR at academic, a fact indicated through their degree of involvement in the specific activities of this concept and increasing actions and programs of social responsibility means higher involvement. Students have engaged in all particular fields of social responsibility, such as tree planting, park fittings, and cleaning or waste collection, supporting those in need, participating in professional educational courses, labor mediation programs, community associations, and university fairs that sustain the level of confidence and happiness of students (Burcea and Marinescu 2011).

There is a need to understand the involvement of private and state universities towards society by means of Social Responsibility initiatives. These universities are serving society by imparting knowledge and empowering students. This study focused on other Social Responsibility initiatives taken up by universities towards society and the environment. It explored the impact of social responsibility initiatives of private and state universities on society and the environment.

\section{Research Methodology:}

As the number of universities in Rajasthan is large; therefore, all of these cannot be taken into our study. Hence, the study will be limited to 20 (10 state and 10 private) Universities of Rajasthan. There are various factors of social responsibility initiatives, but in this study, the researcher will cover Social Responsibility initiatives only towards society and environmental factors and will not cover other factors like economic, legal, etc. This paper used a survey research method based on simple random sampling, and two types of data were used. The researcher will cover only the higher authorities, faculties, and students only for collecting the primary data and will not cover other departments like non-teaching, administration, etc. Secondary data was collected through books, journals, reports, websites, magazines, newspapers, etc.

2.1 Hypothesis: There are three hypotheses have been generated for doing an empirical study on social responsibility initiatives taken up by private and state universities of Rajasthan.

1. H0: There is no significant difference between Social Responsibility initiatives taken up by Rajasthan's private and state universities.

2. H0: There is no significant impact of Social Responsibility initiatives taken up by Rajasthan's private and state universities towards society.

3. H0: There is no significant impact of Social Responsibility initiatives taken up by Rajasthan's private and state universities towards the environment.

A specially designed survey questionnaire was used to compile the information about social responsibility initiatives towards society and the environment. To assess 
the collected data, statistical analytical tools like Excel and SPSS were used.

This study has focused on two factors based on Society and Environment. The elements of these factors are the

Table 1 List of USR Related elements under USR initiatives following in Table 1 on which the analysis and hypothesis testing have been done.

\begin{tabular}{|c|c|c|}
\hline \multicolumn{3}{|c|}{ University Social Responsibility Initiatives } \\
\hline & Society based USRI & Environment based USRI \\
\hline \multicolumn{2}{|c|}{ - Healthcare } & - $\quad$ Recycling of wastage \\
\hline$>$ & Medical Camps & - $\quad$ Tree plantation \\
\hline$>$ & Pulse polio programs & - Water sanitation \\
\hline$>$ & Blood Donation camps & - $\quad$ Pollution control \\
\hline \multicolumn{2}{|c|}{ - Education } & $>\quad$ Air Pollution Control \\
\hline$>$ & Adult literacy classes & $>\quad$ Water Pollution control \\
\hline$>$ & Vocation training to women and youth & $>$ Sound pollution control \\
\hline$>$ & Promotion of free education & - Use of solar energy \\
\hline \multicolumn{2}{|c|}{ - Social awareness programs in various fields } & - Collection and disposal of waste \\
\hline$>$ & AIDS Awareness & - Installing Rainwater Harvesting systems \\
\hline$>$ & Vaccination programs & - Waste water management system \\
\hline$>$ & Family Planning Programme & - Use of Biogas \\
\hline$>$ & Swachch Bharat Abhiyan & - $\quad$ Bio diversity park in the campus \\
\hline$>$ & Ganga Clean Campaign & - Using bicycles inside the campus \\
\hline \multicolumn{3}{|l|}{ - Others } \\
\hline$>$ & \multicolumn{2}{|l|}{ Working for Disability rehabilitation } \\
\hline$>$ & \multicolumn{2}{|l|}{ Adoption of Villages } \\
\hline$>$ & \multicolumn{2}{|l|}{ Agriculture guidance to farmers } \\
\hline$>$ & \multicolumn{2}{|l|}{ Training to students } \\
\hline$>$ & \multicolumn{2}{|l|}{ Slum improvement } \\
\hline$>$ & \multicolumn{2}{|l|}{ Livelihood promotion } \\
\hline$>$ & \multicolumn{2}{|l|}{ Donations to old age homes, hospitals, schools } \\
\hline$>$ & \multicolumn{2}{|l|}{ Helping the underprivileged } \\
\hline$>$ & \multicolumn{2}{|l|}{ Computer literacy classes for rural } \\
\hline$>$ & \multicolumn{2}{|l|}{ Construction of public toilets } \\
\hline$>$ & \multicolumn{2}{|l|}{ Income generation activities for women } \\
\hline
\end{tabular}

\section{Findings and Discussions:}

The above elements listed in Table 1 were used in the questionnaires to know about the social responsibility initiatives taken up by private and state universities of Rajasthan, and correlation and regression analysis have been done to know about the impact of SR initiatives towards society and the environment. The Table 1 shows that universities are doing social responsibility initiatives towards society in terms of education, healthcare, Social awareness programs in various fields and others while these universities are doing social responsibility initiatives towards the environment in terms of recycling of wastage, Tree plantation, Water sanitation, Pollution control, use of solar energy, Collection and disposal 
of waste, Installing Rainwater Harvesting systems, Waste water management system etc.

Now the question arises that what type of SR initiatives are performed by private and state universities in Rajasthan?

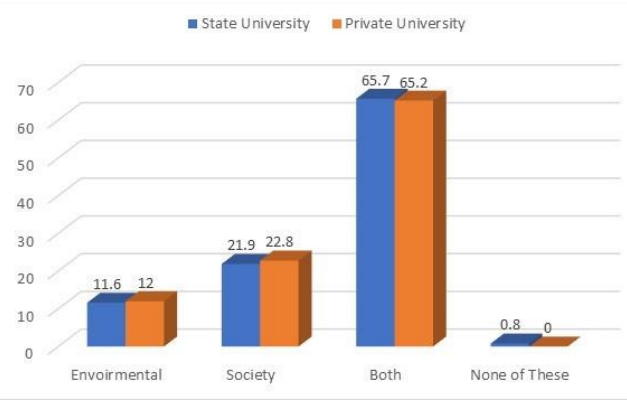

Fig. 1Types of SR Initiative taken by the universities

Figure 1 shows that if the university participates in any SR activity, what kind of activity is based on. In-state university $11.6 \%$ of respondents were based on environment and $65.7 \%$ were based on the environment and society.

Private university-where as in private university $12.0 \%$ of respondents were based on environment, and $65.2 \%$ of respondents were based on society as well as the environment. Private and State Universities are doing more both types of SR initiatives society as well as the environment.

Now the question arises that Universities are focusing more towards either Society or the environment?

Table 2 Difference between Social Responsibility initiatives taken up by private and state universities of Rajasthan towards Society and Environment

\begin{tabular}{|c|c|c|c|c|c|c|c|c|c|c|}
\hline \multicolumn{11}{|c|}{ Independent Samples Test } \\
\hline & & \multicolumn{2}{|c|}{$\begin{array}{c}\text { Levene's Test for } \\
\text { Equality of } \\
\text { Variances }\end{array}$} & \multicolumn{7}{|c|}{ t-test for Equality of Means } \\
\hline & & \multirow{2}{*}{$\mathrm{F}$} & \multirow{2}{*}{ Sig. } & \multirow{2}{*}{$\mathrm{T}$} & \multirow{2}{*}{$\mathrm{df}$} & \multirow{2}{*}{$\begin{array}{l}\text { Sig. (2- } \\
\text { tailed) }\end{array}$} & \multirow{2}{*}{$\begin{array}{c}\text { Mean } \\
\text { Difference }\end{array}$} & \multirow{2}{*}{$\begin{array}{l}\text { Std. Error } \\
\text { Difference }\end{array}$} & \multicolumn{2}{|c|}{$\begin{array}{c}95 \% \text { Confidence Interval } \\
\text { of the Difference }\end{array}$} \\
\hline & & & & & & & & & Lower & Upper \\
\hline \multirow{2}{*}{ Health Care } & $\begin{array}{c}\text { Equal } \\
\text { variances } \\
\text { assumed }\end{array}$ & .321 & .571 & .538 & 301 & .591 & .03621 & .06731 & -.09625 & .16867 \\
\hline & $\begin{array}{c}\text { Equal } \\
\text { variances not } \\
\text { assumed } \\
\end{array}$ & & & .538 & 300.085 & .591 & .03621 & .06732 & -.09627 & .16870 \\
\hline \multirow{2}{*}{ Education } & $\begin{array}{c}\text { Equal } \\
\text { variances } \\
\text { assumed } \\
\end{array}$ & .926 & .337 & .947 & 301 & .344 & .06579 & .06946 & -.07090 & .20248 \\
\hline & $\begin{array}{c}\text { Equal } \\
\text { variances not } \\
\text { assumed }\end{array}$ & & & .947 & 297.733 & .344 & .06579 & .06948 & -.07095 & .20253 \\
\hline \multirow{2}{*}{$\begin{array}{c}\text { Social } \\
\text { Awareness }\end{array}$} & $\begin{array}{c}\text { Equal } \\
\text { variances } \\
\text { assumed }\end{array}$ & .056 & .812 & -.710 & 301 & .478 & -.05005 & .07050 & -.18879 & .08868 \\
\hline & $\begin{array}{c}\text { Equal } \\
\text { variances not } \\
\text { assumed }\end{array}$ & & & -.710 & 300.635 & .478 & -.05005 & .07051 & -.18880 & .08869 \\
\hline \multirow{2}{*}{ Others } & $\begin{array}{c}\text { Equal } \\
\text { variances } \\
\text { assumed }\end{array}$ & .165 & 685 & -.425 & 301 & .671 & -.02905 & .06833 & -.16351 & .10541 \\
\hline & $\begin{array}{c}\text { Equal } \\
\text { variances not } \\
\text { assumed }\end{array}$ & & & -.425 & 300.702 & .671 & -.02905 & .06833 & -.16352 & .10542 \\
\hline
\end{tabular}

Fig. 2 Private and State universities are more focusing on either society or environment?

From the above Figure 2, it shows that the university is focusing more towards either the environment or society. In-state university $31 \%$ of respondents were said more focusing towards environmental, and $69 \%$ of respondents were said more focusing on society, whereas in the private university $25.3 \%$ of respondents were said more concentrated on the environment and $74.6 \%$ of respondents were said more focusing towards society. This figure concluded that private and state universities are doing more social responsibility initiatives towards society rather than the environment.

\subsection{Hypotheses Testing}

H01: There is no significant difference between Social Responsibility initiatives taken up by Rajasthan's private and state universities. 


\begin{tabular}{|c|c|c|c|c|c|c|c|c|c|c|}
\hline \multirow{7}{*}{ Environment } & $\begin{array}{c}\text { Equal } \\
\text { variances } \\
\text { assumed } \\
\begin{array}{c}\text { Equal } \\
\text { variances not } \\
\text { assumed }\end{array}\end{array}$ & .317 & .574 & 1.094 & 301 & .275 & .07327 & .06697 & -.05851 & .20505 \\
\cline { 2 - 10 } & & & 1.094 & 300.926 & .275 & .07327 & .06696 & -.05850 & .20504 \\
\hline
\end{tabular}

The Output Source: IBM-SPSS 22

The independent Samples T-test as seen in Table 2, which indicates the outcomes best suited to the independent T-test. There are two components which contain separate data: (a) Leven's Variance Test and (b) T-test for Equality of Means.

The Levene test's p-value for healthcare in this examination is 0.571 (more than 0.05 ), but in the first row of the t-test equality, we can see that its significant value is 0.591 (more than 0.05). It can be inferred that there is no statistically important gap in health care between private and state universities in Rajasthan (p-value is greater than 0.05).

In the case of education, the Levene's p-value is 0.926 (more than 0.05); we can see this for Equality of Means in the firstrow t-test where the significant value is 0.344 and is above 0.05 . It can be inferred that there is no statistically relevant gap in education between Rajasthan's private and state universities ( $\mathrm{p}$ value is more than 0.05).

The Levene test's p-value is 0,056 , which is more than 0.05 in the case of social awareness; we can therefore see that the equality of mean value in the first row of t-tests is 0.478 , that is more than 0.05 . It can be inferred that there is no statistically significant difference in social awareness (p-value is more than 0.05 ) among private and state universities in Rajasthan.

Table 3 Multiple Correlation Analysis

\begin{tabular}{|c|c|c|c|c|c|c|}
\hline \multicolumn{7}{|c|}{ Correlations } \\
\hline & & & Health Care & Education & Social Awareness & Others \\
\hline \multirow{3}{*}{ State University } & \multirow{3}{*}{ SR Activities } & Pearson Correlation & .275 & .327 & .328 & .360 \\
\hline & & Sig. (2-tailed) & .001 & .000 & .000 & .000 \\
\hline & & $\mathrm{N}$ & 152 & 152 & 152 & 152 \\
\hline \multirow{3}{*}{ Private University } & \multirow{3}{*}{ SR Activities } & Pearson Correlation & .140 & .128 & .188 & .149 \\
\hline & & Sig. (2-tailed) & .016 & .015 & .008 & .011 \\
\hline & & $\mathrm{N}$ & 152 & 152 & 152 & 152 \\
\hline
\end{tabular}

The Output Source: IBM-SPSS 22

On the basis of the state university, the above Table no. 3 and figure showed that a significant relationship exists between social responsibility initiatives taken up by Rajasthan's state universities towards society. Other initiatives taken by state
The p-value determined from the Levene's test is 0.165 (more than 0.05), and as it can be found for Equality of Means in the first row of the t-test, the significant value is 0.671 , which is greater than 0.05 . It indicated that there is no statistically significant disparity among private and state universities of Rajasthan regarding other initiatives ( $p$-value is more than 0.05).

In the environmental case, the p-value of the Levene's test is 0.574 , which is greater than 0.05 , and as it can be noticed that the equality of mean value in the first row of t-tests is 0.275 (more than 0.05). It indicates that there is no statistically significant difference among private and state universities of Rajasthan regarding the environment ( $p$-value is more than $0.05)$.

On the basis of Table No. 2, it can be concluded that null hypothesis 1 has been accepted, which has shown that there is no substantial gap among Social Responsibility initiatives taken up by private and state universities of Rajasthan.

H02: There is no significant impact of Social Responsibility initiatives taken up by private and state universities of Rajasthan towards society universities have been found to have the highest Pearson correlation ' $r$ ' value of 0.360 and significance value ( $p$ value) is 0.000 which suggests that the State Universities of Rajasthan have a statistically significant positive correlation exist between other initiatives and social responsibility initiatives. 
In the context of Social Awareness, the ' $r$ ' value of Pearson correlation is 0.328 at significance (p-value) 0.000 . That is smaller than the significance value 0.05 of the alpha level, which suggests a statistically positive significant correlation between social awareness and social responsibility initiatives at Rajasthan's State Universities.

Education initiatives taken up by the state universities have the ' $r$ ' value of Pearson correlation is 0.327 at significance ( $p$ value) 0.000 , which means a positive statistically significant correlation among education initiatives and social responsibility initiatives at Rajasthan's State Universities.

Health care has a Pearson correlation 'r' value of 0.275 and the p-value of 0.001 , which means a statistically significant correlation between health care and social responsibility initiatives at Rajasthan's state universities.

Though there is a significant relationship between social responsibility initiatives taken by Rajasthan State Universities towards society based on private universities, Social Awareness has found the maximum ' $r$ ' value of Pearson correlation is 0.188 at significance ( $\mathrm{p}$-value) 0.008 , which means that Rajasthan State Universities have a statistically significant optimistic correlation between social awareness and social responsibility initiatives.

In the context of other initiatives taken up by the private universities, has ' $r$ ' value of Pearson correlation is 0.149 , and the significant ( $p$-value) is 0.011 , which indicates an optimistic statistically significant correlation between other initiatives and social responsibility initiatives at private universities of Rajasthan.

Health care has ' $r$ ' value of Pearson correlation is 0.140 and $p$ value is 0.016 , which shows that a positive statistically significant correlation in between health care and social responsibility initiatives at private universities of Rajasthan

Education initiative taken by Rajasthan's private universities has ' $r$ ' value of Pearson correlation is 0.128 , and a significant p-value is 0.015 , which shows that an optimistic statistically significant correlation among education initiatives and social responsibility initiatives at state universities of Rajasthan.

Table 4 Correlation comparison analysis of social responsibility initiatives taken up by private and state universities of Rajasthan towards society

\begin{tabular}{|c|c|c|c|}
\hline \multicolumn{4}{|c|}{$\begin{array}{c}\text { Correlation comparison analysis of social responsibility initiatives } \\
\text { taken up by private and state universities of Rajasthan towards } \\
\text { society }\end{array}$} \\
\hline \multirow{2}{*}{\multicolumn{2}{|c|}{ Different Identified Variables }} & $\begin{array}{c}\text { State } \\
\text { University } \\
\end{array}$ & $\begin{array}{c}\text { Private } \\
\text { University } \\
\end{array}$ \\
\hline & & SR Activities & SR Activities \\
\hline Health Care & $\begin{array}{c}\text { Pearson } \\
\text { Correlation }\end{array}$ & 0.275 & 0.140 \\
\hline Education & $\begin{array}{c}\text { Pearson } \\
\text { Correlation }\end{array}$ & 0.327 & 0.128 \\
\hline $\begin{array}{c}\text { Social } \\
\text { Awareness }\end{array}$ & $\begin{array}{c}\text { Pearson } \\
\text { Correlation }\end{array}$ & 0.328 & 0.188 \\
\hline
\end{tabular}

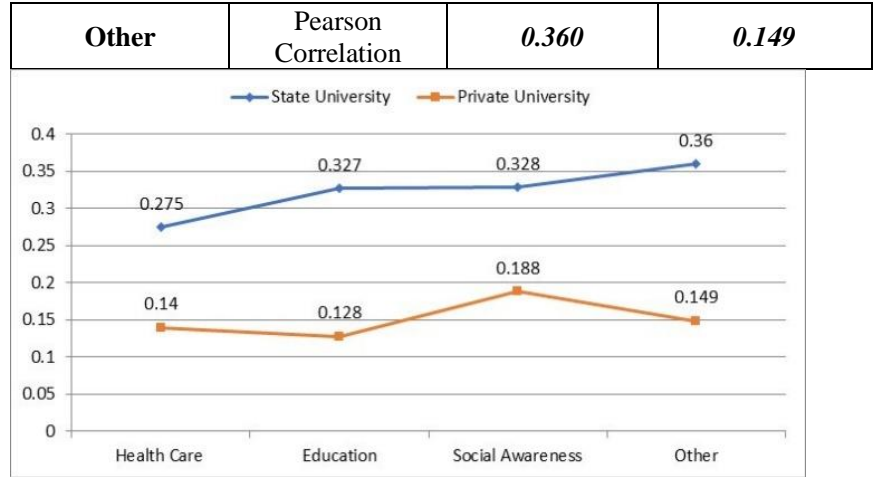

Fig. 3 Correlation comparison analysis of social responsibility initiatives taken up by private and state universities of Rajasthan towards society

It is evident from the above Table no. 4 and Figure 3 that the social responsibility initiative as beneficial to society. It has been analyzed that the social responsibility initiative, Pearson correlation value of state university, is more than a private university. It implies that social responsibility initiative in-state university have a more positive attitude towards society.

\subsection{Regression Analysis on Social Responsibility initiatives taken up by private and state universities of Rajasthan towards society}

Table 5 Model Summery

\begin{tabular}{|c|c|c|c|c|c|c|}
\hline \multicolumn{7}{|c|}{ Model Summary $^{|c|}$} \\
\hline \multicolumn{2}{|c|}{ University } & $\mathrm{R}$ & $\begin{array}{c}\mathrm{R} \\
\text { Square }\end{array}$ & $\begin{array}{c}\text { Adjusted } \\
\text { R Square }\end{array}$ & $\begin{array}{c}\text { Std. } \\
\text { Error of } \\
\text { the } \\
\text { Estimate }\end{array}$ & $\begin{array}{c}\text { Durbin- } \\
\text { Watson }\end{array}$ \\
\hline $\begin{array}{c}\text { State } \\
\text { University }\end{array}$ & 1 & .376 & .141 & .118 & .49329 & 1.572 \\
\hline $\begin{array}{c}\text { Private } \\
\text { University }\end{array}$ & 1 & .222 & .049 & .023 & .41651 & 1.749 \\
\hline
\end{tabular}

The Output Source: IBM-SPSS 22

$\mathrm{R}$ Square is 0.141 in the Model Description in table 5 above on the basis of the state university, which explains 14.1 percent of the variability with a significant impact on social responsibility initiatives taken by Rajasthan state universities towards society. Whereas on the source of private universities, R Square value is 0.049 , which clarifies $4.9 \%$ of the variability with significant effect on social responsibility initiatives taken up by Rajasthan's private universities towards society.

The table above shows the description of the multiple linear regression model and the final fit figures. $\mathrm{R}$ of our model in state and private universities has been found to be .376 and .222 with R2=.141 and.049, respectively. This suggests that 14.1 percent and 4.9 percent of the result's variation were clarified by linear regression. The Durbin-Watson in state and private universities $\mathrm{d}=1.572$ and 1.749 , which is in between two critical values of $1.5<\mathrm{d}<2.5$. Consequently, we can assume 
there is no first order linear auto-correlation in our multiple linear regression results.

Table 6 ANOVA goodness of fit (GOF)

\begin{tabular}{|c|c|c|c|c|c|c|c|}
\hline \multicolumn{8}{|c|}{ ANOVA $^{a}$} \\
\hline \multicolumn{3}{|c|}{ University } & Sum of Squares & $\mathrm{df}$ & Mean Square & $\mathrm{F}$ & Sig. \\
\hline \multirow{3}{*}{ State University } & \multirow{3}{*}{1} & Regression & 5.842 & 4 & 1.460 & 6.002 & .000 \\
\hline & & Residual & 35.527 & 147 & .243 & & \\
\hline & & Total & 41.369 & 151 & & & \\
\hline \multirow{3}{*}{ Private University } & \multirow{3}{*}{1} & Regression & 1.316 & 4 & .329 & 1.897 & .014 \\
\hline & & Residual & 25.501 & 147 & .173 & & \\
\hline & & Total & 26.818 & 151 & & & \\
\hline
\end{tabular}

The Output Source: IBM-SPSS 22

In the ANOVA table no. 6, the F-ratio checks whether the overall regression model is a useful data fit. The table indicates that social responsibility initiatives are taken up by Rajasthan's state and private universities towards society. In both state and Table 7 Coefficients

\begin{tabular}{|c|c|c|c|c|c|c|c|}
\hline \multicolumn{8}{|c|}{ Coefficients $^{\mathrm{a}}$} \\
\hline \multirow{2}{*}{\multicolumn{3}{|c|}{ University }} & \multicolumn{2}{|c|}{ Unstandardized Coefficients } & \multirow{3}{*}{$\frac{\text { Standardized Coefficients }}{\text { Beta }}$} & \multirow{3}{*}{$\begin{array}{c}\mathrm{T} \\
16.559\end{array}$} & \multirow{3}{*}{$\begin{array}{l}\text { Sig. } \\
.000\end{array}$} \\
\hline & & & \multirow{2}{*}{$\frac{\mathrm{B}}{1.704}$} & \multirow{2}{*}{$\begin{array}{c}\text { Std. Error } \\
.103\end{array}$} & & & \\
\hline \multirow{5}{*}{ State University } & \multirow{5}{*}{1} & (Constant) & & & & & \\
\hline & & Health Care & .218 & .157 & .249 & 1.388 & .001 \\
\hline & & Education & .060 & .139 & .072 & .432 & .000 \\
\hline & & Social Awareness & .078 & .166 & .092 & .467 & .000 \\
\hline & & Others & .378 & .211 & .433 & 1.791 & .000 \\
\hline \multirow{5}{*}{ Private University } & \multirow{5}{*}{1} & (Constant) & 2.079 & .091 & & 22.953 & .000 \\
\hline & & Health Care & 1.160 & .115 & .116 & .587 & .016 \\
\hline & & Education & .037 & .132 & .051 & .280 & .015 \\
\hline & & Social Awareness & .131 & .151 & .188 & .868 & .008 \\
\hline & & Others & .326 & .172 & .155 & .704 & .011 \\
\hline
\end{tabular}

The Output Source: IBM-SPSS 22

Unstandardized parameters show how much the dependent variable varies from an independent variable as all other independent variables are kept constant. The above table reveals that social responsibility initiatives taken up by Rajasthan's state universities toward society are essential predictors based on state universities, as a meaningful meaning in all cases of less than 0.05 implies the null hypothesis is rejected. The study concluded that social responsibility initiatives undertaken by state universities in Rajasthan have a huge impact on society. private universities, the value is smaller than 0.05 , which indicates that the regression model is a good match for the results. The F-test is very significant, so we can conclude that the model describes a large quantity of the variation in social responsibility initiatives towards society. 
Table 8 Correlation Analysis

\begin{tabular}{|c|c|c|c|}
\hline \multicolumn{3}{|c|}{ Correlations } \\
\hline \multirow{3}{*}{$\begin{array}{c}\text { University } \\
\text { State } \\
\text { University }\end{array}$} & \multirow{2}{*}{ SR Activities } & $\begin{array}{c}\text { Pearson } \\
\text { Correlation }\end{array}$ & $.310^{* *}$ \\
\cline { 3 - 4 } & & Sig. (2-tailed) & .000 \\
\cline { 3 - 4 } & & $\mathrm{N}$ & 152 \\
\hline \multirow{2}{*}{$\begin{array}{c}\text { Private } \\
\text { University }\end{array}$} & \multirow{2}{*}{ SR Activities } & $\begin{array}{c}\text { Pearson } \\
\text { Correlation }\end{array}$ & $.201^{*}$ \\
\cline { 3 - 4 } & & Sig. (2-tailed) & .013 \\
\cline { 3 - 4 } & & $\mathrm{N}$ & 152 \\
\hline
\end{tabular}

The Output Source: IBM-SPSS 22

Table 8 reveals that, based on the State University, a significant relationship exists between the initiatives of social responsibility taken up by the State Universities of Rajasthan towards the environment. It has been found that the state university's environment initiatives have ' $r$ ' value of Pearson correlation is 0.310 , and significant (p-value) is 0.000 , indicating an optimistic statistically substantial correlation between environment and social responsibility initiatives at state universities of Rajasthan.

Whereas on the basis of the private university there is a significant relationship between social responsibility initiatives taken up by state universities of Rajasthan towards the environment. It has found that the private universities environment initiatives have ' $r$ ' value of Pearson correlation is 0.201 at significant (p-value) is 0.000 , which means there is a positive statistically significant correlation between environment and social responsibility initiatives at private universities of Rajasthan.

Table 9 Correlation comparison analysis of social responsibility initiatives taken up by private and state universities of Rajasthan towards the environment

\begin{tabular}{|c|c|c|c|}
\hline \multicolumn{4}{|c|}{$\begin{array}{l}\text { Correlation comparison analysis of social responsibility initiatives } \\
\text { taken up by private and state universities of Rajasthan towards } \\
\text { environment }\end{array}$} \\
\hline \multirow{2}{*}{\multicolumn{2}{|c|}{ Different Identified Variables }} & $\begin{array}{c}\text { State } \\
\text { University }\end{array}$ & $\begin{array}{c}\text { Private } \\
\text { University }\end{array}$ \\
\hline & & SR Initiatives & SR Initiatives \\
\hline Environment & $\begin{array}{c}\text { Pearson } \\
\text { Correlation }\end{array}$ & 0.310 & 0.201 \\
\hline
\end{tabular}

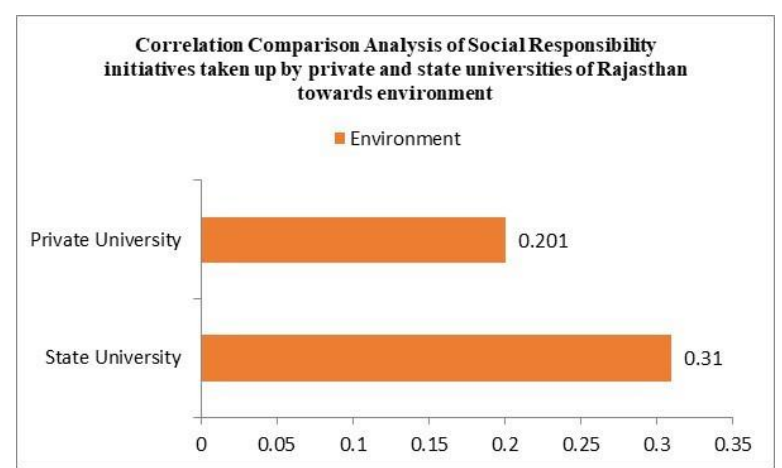

Fig. 4 Correlation comparison analysis of social responsibility initiatives taken up by private and state universities of Rajasthan towards the environment

It is evident from the above table and charts that the social responsibility initiative as beneficial to the environment. It has been analyzed that the social responsibility initiative, Pearson correlation value of state university, is more than a private university. It implies that social responsibility initiative in-state university have a more positive attitude towards the environment.

\subsection{Regression Analysis on Social Responsibility} initiatives taken up by private and state universities of Rajasthan towards the environment

Table 10 Model Summary ${ }^{\mathrm{b}}$

\begin{tabular}{|c|c|c|c|c|c|c|}
\hline \multicolumn{7}{|c|}{ Model Summary $^{\text {b }}$} \\
\hline University & $\mathrm{R}$ & $\begin{array}{c}\mathrm{R} \\
\text { Square }\end{array}$ & $\begin{array}{c}\text { Adjusted } \\
\text { R Square }\end{array}$ & $\begin{array}{c}\text { Std. } \\
\text { Error of } \\
\text { the } \\
\text { Estimate }\end{array}$ & $\begin{array}{c}\text { Durbin- } \\
\text { Watson }\end{array}$ \\
\hline $\begin{array}{c}\text { State } \\
\text { University }\end{array}$ & 1 & $.310^{\mathrm{a}}$ & .096 & .090 & .50104 & 1.542 \\
\hline $\begin{array}{c}\text { Private } \\
\text { University }\end{array}$ & 1 & $.201^{\mathrm{a}}$ & .040 & .034 & .41420 & 1.784 \\
\hline
\end{tabular}

The Output Source: IBM-SPSS 22

Based on state universities, R Square is 0.096 in the Model Description in the above table, which describes 9.6 percent of the variability with a significant impact on Rajasthan's private university's social responsibility initiatives towards the environment.

Whereas R Square is 0.040 on the basis of private universities, which describes 4.0 percent of the variability with a major impact on environmental initiatives taken up by private universities in Rajasthan on social responsibility.

The table above shows the description of the multiple linear regression model and the final fit figures. $\mathrm{R}$ of our model in state and private universities has been found to be.310 and.201 with $\mathrm{R} 2=.096$ and.040, respectively. This suggests that $9.6 \%$ and $4.0 \%$ of the variation of the results were described by linear regression. In state and private universities, Durbin-Watson $\mathrm{d}=$ 
1.542 and 1.784 , which is in between two critical values of 1.5 $<\mathrm{d}<2.5$. Consequently, we can assume there is no first order linear auto-correlation in our multiple linear regression results.

Table 11 ANOVA goodness of fit (GOF)

\begin{tabular}{|c|c|c|c|c|c|c|c|}
\hline \multicolumn{7}{|c|}{ ANOVA $^{\text {a }}$} \\
\hline \multicolumn{2}{|c|}{ University } & $\begin{array}{c}\text { Sum of } \\
\text { Square } \\
\mathrm{s}\end{array}$ & $\mathrm{df}$ & $\begin{array}{c}\text { Mean } \\
\text { Squar } \\
\mathrm{e}\end{array}$ & $\mathrm{F}$ & Sig. \\
\hline \multirow{4}{*}{$\begin{array}{c}\text { State } \\
\text { Universit } \\
\mathbf{y}\end{array}$} & 1 & $\begin{array}{c}\text { Regressio } \\
\mathrm{n}\end{array}$ & 3.964 & 1 & 3.964 & $\begin{array}{c}15.79 \\
1\end{array}$ & $\begin{array}{c}.00 \\
0\end{array}$ \\
\cline { 2 - 8 } & Residual & 37.405 & $\begin{array}{c}15 \\
0\end{array}$ & .251 & & \\
\cline { 2 - 8 } & & Total & 41.369 & $\begin{array}{c}15 \\
1\end{array}$ & & & \\
\hline \multirow{4}{*}{$\begin{array}{c}\text { Private } \\
\text { Universit } \\
\mathbf{y}\end{array}$} & 1 & $\begin{array}{c}\text { Regressio } \\
\mathrm{n}\end{array}$ & 1.083 & 1 & 1.083 & 6.314 & $\begin{array}{c}.01 \\
3\end{array}$ \\
\cline { 2 - 8 } & Residual & 25.734 & $\begin{array}{c}15 \\
0\end{array}$ & .172 & & \\
\cline { 2 - 8 } & Total & 26.818 & $\begin{array}{c}15 \\
1\end{array}$ & & & \\
\hline
\end{tabular}

The Output Source: IBM-SPSS 22

The F-ratio checks whether the overall regression model is a good fit for the details in the ANOVA table. The table indicates that social responsibility initiatives are taken up by state and private universities of Rajasthan towards society. In both state and private universities, the value is smaller than 0.05 , which indicates that the regression model is a decent fit for the results. The F-test is exceptionally significant, so we can conclude that the model describes a considerable quantity of the variation towards the environment in social responsibility initiatives.

Table 12 Coefficients

\begin{tabular}{|c|c|c|c|c|c|c|c|}
\hline \multicolumn{8}{|c|}{ Coefficients $^{\mathrm{a}}$} \\
\hline \multirow{2}{*}{\multicolumn{3}{|c|}{ University }} & \multicolumn{2}{|c|}{$\begin{array}{c}\text { Unstandardiz } \\
\text { ed } \\
\text { Coefficients }\end{array}$} & \multirow{2}{*}{$\begin{array}{c}\begin{array}{c}\text { Standardiz } \\
\text { ed }\end{array} \\
\begin{array}{c}\text { Coefficien } \\
\text { ts }\end{array} \\
\text { Beta }\end{array}$} & \multirow[t]{2}{*}{$\mathrm{t}$} & \multirow[t]{2}{*}{$\begin{array}{c}\text { Sig } \\
\text {. }\end{array}$} \\
\hline & & & B & $\begin{array}{l}\text { Std. } \\
\text { Error }\end{array}$ & & & \\
\hline \multirow{2}{*}{$\begin{array}{c}\text { State } \\
\text { Universi } \\
\text { ty }\end{array}$} & \multirow{2}{*}{1} & (Constant) & $\begin{array}{c}1.79 \\
2\end{array}$ & .090 & & $\begin{array}{c}19.81 \\
2\end{array}$ & $\begin{array}{c}.00 \\
0\end{array}$ \\
\hline & & $\begin{array}{c}\text { Environm } \\
\text { ent }\end{array}$ & .282 & .071 & .310 & 3.974 & $\begin{array}{c}.00 \\
0\end{array}$ \\
\hline \multirow{2}{*}{$\begin{array}{c}\text { Private } \\
\text { Universi } \\
\text { ty }\end{array}$} & \multirow{2}{*}{1} & (Constant) & $\begin{array}{c}2.02 \\
9\end{array}$ & .070 & & $\begin{array}{c}29.18 \\
5\end{array}$ & $\begin{array}{c}.00 \\
0\end{array}$ \\
\hline & & $\begin{array}{c}\text { Environm } \\
\text { ent }\end{array}$ & .144 & .057 & .201 & 2.513 & $\begin{array}{c}.01 \\
3\end{array}$ \\
\hline
\end{tabular}

The Output Source: IBM-SPSS 22

When all other independent variables are kept constant, unstandardized coefficients mean how often the dependent management in challenging situations, diverse styles of schooling, giving them meaningful education, making them mindful of their obligation for Society, etc., eventually leading to group empowerment. variable differs from an independent variable. From the above table, based on state university, social responsibility initiatives taken up by state universities of Rajasthan towards the environment are significant. A significant value is .000 , which is smaller than 0.05 , indicates the rejection of the null hypothesis. The study showed that there is a considerable impact of social responsibility initiatives taken up by state universities of Rajasthan towards the environment.

Likewise, based on private university social responsibility initiatives taken up by Rajasthan's state universities towards society are significant predictors. A significant value is .013 which is less than 0.05 , indicating that the null hypothesis is rejected. The analysis concluded that Rajasthan's private universities have a significant impact on social responsibility initiatives towards the environment.

The results of this analysis indicate that in terms of university social responsibility (USR), all private and state universities are socially responsible, but they are somehow more focused on society rather than the environment. This study also shows that there is a significant impact of social responsibility initiatives of private and state universities towards society and the environment and all the twenty universities have covered areas of society in terms of healthcare, education, Social awareness programs in various fields and others and also covered areas of environment in terms of Tree plantation, water sanitation, pollution control, Recycling of waste products, use of solar energy, collection and disposal of waste, etc. The survey study provided a roadmap to Universities for adopting social responsibility initiatives to develop the community and the environment. This paper finds that Universities are appealing in SR activities but these activities required more attention and proper guidance, which can be based on appropriate policy formulation on University social responsibility initiatives.

\section{Conclusion}

University Social Responsibility can be defined in this definition-"University Social Responsibility is a strategic mechanism for acquiring goodwill and emulative advantages for universities which is seen as a cluster of social responsibility initiatives taken by universities for community growth and the environment that improve the skills of students, such as fundraising, Teamwork, project

The hypothesis testing results show that there is no statistically significant difference between private and state universities of Rajasthan towards Society and the environment, but the correlation and regression results indicate that there is a significant impact of social responsibility initiatives taken up 
by private and state universities of Rajasthan towards Society and environment. This paper finds that Universities are engaging in SR activities, but these activities are not adequately uploaded on university websites. Private and State Universities are doing more SR initiatives towards Society rather than the environment. Studies so far have been conducted outside India, which makes this research a relevant evaluation in the Indian sense as it discusses critical functional problems for Society and the environment. This study made the students aware of the critical issues like Tree plantation, Recycling of wastage, etc. surrounding them. SR Initiatives have done by universities

\section{References}

Burcea, Marin, and Paul Marinescu. "Students' Perceptions on Corporate Social Responsibility at the Academic Level. Case Study: The Faculty of Administration and Business, University of Bucharest." Amfiteatru Economic Journal 13.29 (2011): 207-220. http://hdl.handle.net/10419/168716

Capocchi, Alessandro, et al. "The Important Role of Universities in Enhancing Sustainability: The Case of the University of Milano-Bicocca." Social Responsibility and Sustainability. Springer, Cham, 2019. 389-410. https://doi.org/10.1007/978-3-030-03562-4_20

Chopra, Abha, and Shruti Marriya. "Corporate social responsibility and education in India." (2014). http://dspace.chitkara.edu.in/xmlui/handle/1/62

Dahan, Gresi Sanje, and Isil Senol. "Corporate social responsibility in higher education institutions: Istanbul Bilgi University case." American International Journal of Contemporary Research 2.3 (2012): 95-103.

Garde Sánchez, Raquel, Manuel Pedro Rodríguez Bolívar, and Antonio M. López-Hernández. "Online disclosure of university social responsibility: a comparative study of public and private US universities." Environmental Education Research 19.6 (2013): 709-746. https://doi.org/10.1080/13504622.2012.749976

Gomez, Lina M., Yanitzary Alvarado Naveira, and Aileen Pujols Bernabel. "Implementing University Social Responsibility in the Caribbean: Perspectives of Internal Stakeholders." RIDU 12.1 (2018): 101-120. http://dx.doi.org/10.19083/ridu.12.714.

Goncu, Barika, and Vehbi Gorgulu. "University Social Responsibility Towards Sustainable Coexistence of Humans and Animals on Campus: Case Study on Bilgi Animal Friends Society." Communication Management Review 3.01 (2018): 80-100. https://doi.org/10.22522/cmr20180130

Karima, Risuke, Yoshito Oshima, and Kazuo Yamamoto. "Identification of subjects for Social Responsibility Education at Universities and the present activity of enhanced skills of the students like fund-raising, team work, project management in difficult circumstances, teamwork, different types of learning, etc. We should then end by suggesting that being socially responsible in today's Society is really important. For SR initiatives to change Society, all educational institutions are increasingly mindful of this and are actively interested in creating future Society members. The education sector can contribute more to the moral development of students by these initiatives. Implementing SR strategies in higher education institutions provide a real competitive advantage and a positive reputation.

the University of Tokyo." Environ Sci 13.6 (2006): 327-337.

Kouatli, Issam. "The contemporary definition of university social responsibility with quantifiable sustainability." Social responsibility journal (2019). https://doi.org/10.1108/SRJ-10-2017-0210

Lahaye, Laurent, et al. "CSR Initiatives in two Higher Education Institutions from Belgium and Romania." International Conference "Risk in Contemporary Economy" "Dunarea de Jos" University of Galati-Faculty of Economics and Business Administration. 2012.

Mehta, Sandhya rao. "Corporate social responsibility (csr) and universities: towards an integrative approach." International Journal of Social Science and Humanity 1.4 (2011): 300.

DOI:10.7763/IJSSH.2011.V1.55

Mishra, Geeta. "Reflecting Responsible Initiatives for Successful CSR In Context of Higher Education Institutions." Journal of Business Management \& Social Sciences Research 2.6 (2013): 36-42.

Nandi, Veena Tewari. "Corporate Social Responsibility: Relevance In Education and Technology: INDIA." Proceedings of 6th International Business and Social Sciences Research Conference. 2013.

Peicheva, Miroslava. "Social Responsibility of the Universities in Europe-Research of Diversity of Practices." Economic Alternatives 2 (2019): 235250.

Shaari, Roziana, et al. "The impact of university social responsibility towards producing good citizenship: Evidence from Malaysia." International Journal of Organizational Leadership 7 (2018): 374-382. SSRN: https://ssrn.com/abstract=3337651

Shivakumar, G. (2013, April 17). "India is set to become the youngest country by 2020." from https://www.thehindu.com/news/national/india-isset-to-become-the-youngest-country-by2020/article4624347.ece.

TARA Panjwani. (2019, April 08). "University Social Responsibility in India and Beyond." from https://www.ukibc.com/university-socialresponsibility/.

Valdez, N. "Corporate social responsibility Practices among private school organizations: the Philippine 
experience." International Conference on Business and Management. Vol. 6. No. 7. 2012.

Vasilescu, Ruxandra, et al. "Developing university social responsibility: A model for the challenges of the new civil society." Procedia-Social and Behavioral Sciences 2.2 (2010): 4177-4182.

https://doi.org/10.1016/j.sbspro.2010.03.660 